\title{
IMPROVING THE QUALITY OF PRIMARY HEALTH SERVICES IN THE PERSPECTIVE OF PARTICIPATORY GOVERNANCE
}

\author{
Husni Machmuddin \\ husnifikril@gmail.com \\ Andi Agustang \\ andi.agustang@unm.ac.id \\ Andi Asrifan \\ andiasrifan@gmail.com
}

\begin{abstract}
The application of good governance within governance prerequisite that cannot be left out is the participation of the community in public policy. The main prerequisites were when the Government implemented the autonomous region with the principle of decentralization, community participation. It involves all aspects of the implementation of the development in areas starting from planning to supervision. Participatory governance is governance putting citizens or non-government as an individual or organization as a viable social stakeholder in making public policy that has just dominated the Government. Model of participatory governance policy in the primary health services is eligible to be developed by optimizing and strengthening cooperation intersectional, increasing the motivation of health workers as well as eliminating social and cultural barriers in the community.
\end{abstract}

Keywords: Participatory governance, primary health services

\section{INTRODUCTION}

There is an understanding that the community is the owner of the public service. Therefore, the community should be included in making decisions related to the implementation of the public service. There will be many advantages by engaging the community in decision making related to public service. There is an increase in the quality of the resulting public policy the Government that in turn will be very beneficial to the community as a policy goal. In addition to creating benefits for the community, public participation in decision-making will also provide benefits for the Government. It means that the government will be more powerful in the institutional capacity in the presence of policy produced democratically.

The community participation in the public service is crucial. Therefore, the community could play a role such as formulating criteria for service, learning how to set up the service, granting each engagement, adjusting the mechanism of public complaints and monitoring as well as evaluating the implementation of the public service. Thus, the Government and the community can jointly build commitment to creating quality public services. 
The first barrier is the problem of laziness to participating in research conducted by Abelson and Elsey (1998) [1] concluding that in the end, there is a tendency of participation that is issue-issued. It means that the community will participate in the simple problems by not using a high analytical and theoretical ability toward a problem. Another barrier is the problem of the implementation of exit and voice within the public service, as revealed by Alberth Hiischman in Kurniawan (2008) [2]. He states that the exit mechanism is usually hampered by expensive service provision so that the citizens are reluctant to do that. The barrier on the mechanism of voice is the absence of a channel for it. These phenomena show that the participation of the community in the public service is still poor.

\section{THEORETICAL FRAMEWORK}

The concept of Participatory Governance

The concept of participatory governance in social sciences has prompted a new philosophy to develop this concept from a broader perspective. Geissell (2004) [3] in his article states: "Participatory Governance Theoretic-analytical Approaches and a Case Study (Traditional Network)" The models of participatory governance are identified into three perspectives. They are global governance, participatory governance, and participatory governance in non-state transnational networks.

From the above description, it can be concluded that participatory governance is a Government putting the citizens or non-government as an individual or organization for social development as stakeholders in decision making for public policy that dominated the government. Regardless of whether the Government is using a system of direct democracy or indirect democracy or by mixing the two systems of democracy. Citizen participation at the level of concepts, as well as practical studies, can be created without regard to any democratic system that is used. Thus, from this perspective, participation is no longer understood as a means or method, but it is understood as a process and goal.

The service quality is the difference between the perception and experience of consumers, who state an allegation of satisfaction. Whether the public service has a high quality or not, can be understood as a disproportionate gap both in public organizations are recognized (Parasuraman et al., 1985). [4] 
According to Grönroos (1990),[5] there are two types of service quality, namely: First, the technical quality / technical quality (outcome dimension) related to the perceived output quality customer service. The components are divided into three types, namely: search quality (can be evaluated before purchase, such as price), quality experience (can only be evaluated after consumption, e.g. punctuality, speed of service and neatness results), and Credence quality (though a difficult customer has evaluated consume services, such as the quality of cardiac surgery). Second, the quality of the functional / functional quality (process-related dimension) about the quality of service delivery means or involves the transfer of technical quality, outputs or outcomes from the service provider to the customer. It is examples of the appearance and behavior of the waiter. When compared with the technical quality, functional quality dimension is perceived subjective and could not be evaluated as objectively as technical quality.

Participatory Governance policy models in health care deserve to be developed (Pollit, 1999) [6] is due to: 1) transaction that occurs between providers and users of services in the public sector tend to be more complex than those faced by service users in a normal market. 2) The consumer sector public that they are not just consumers, but it is also a citizen of course it has certain unique implications. Hospital as a health care provider institution also still needs to develop appropriate service quality expectations of the customer.

In Service Quality Conceptual Model, there are five services prose possibility of a gap that causes the difference in perception of service quality. Quality of care is the degree of concordance between the expectations / desires and perceptions of service received by the customer. There needs to be an effort to eliminate the differences in perception (gap) on the quality of service of the provider to the customer. As the effort is to improve the suitability on meeting the needs and expectations of the various dimensions of service quality. Fulfillment waiter is quality dimensions according to the needs and expectations of the community will provide a positive perception of the quality of services provided.

\section{Public Service}

Service is a translation of the word "service" is often translated into services. According to Kotler (1995) [7], the service is any action or activity that can be offered by one party to another that is essentially intangible and does not result in any ownership.

Public services can be defined; any services performed by the Central Government, in the region, and the State-Owned Enterprises environment or provincial enterprises in the form of goods or services, either in an effort to meet the needs of society as well as in the implementation of the laws and invitation (Decision MENPAN Number 63/2003). 
In connection with the assessment of service quality Morgan and Murgatroyd (1994) [8] The portrait of the Triangle of Service Quality. The costumer loyality, the future of hospitality marketing Lewis (1999) [9]

As for The Triangle of Quality Service, is as follows:

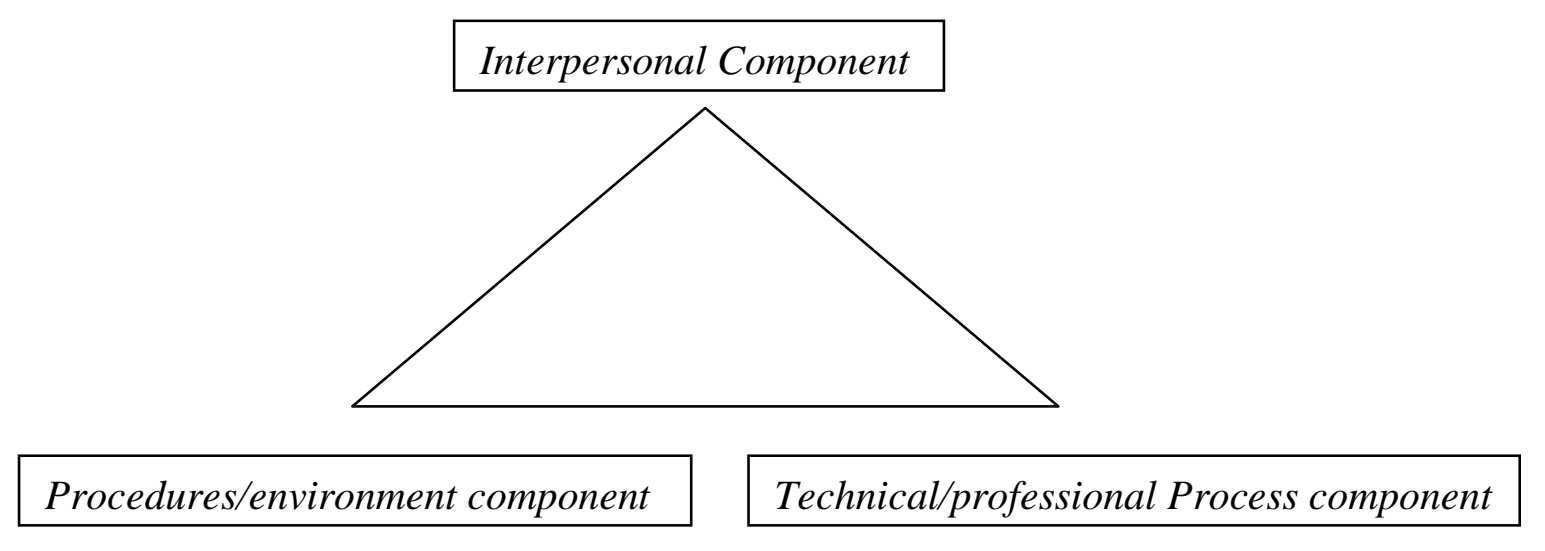

Figure 1. The Triangle of Service Quality

Source: Warella (2004:74) tahun 1997[10]

This model is an equilateral triangle where the peak is a component of Interpersonal. Of a service, whereas on the left side of the triangle is the physical context, procedures and process components. On the right, side is the technical or professional component in delivering the service. The assumption of this model is the need for sustained balance of these three components in providing a good service. For example, too much emphasis on process and procedure will give the impression that services convoluted and complicated.

\section{Basic Health Care}

Public Service Health Division has been supported by Law No. 23 in 1992 on Public Health Systems. This law has set a range of issues related to health problems, both of which include philosophy, arrangement between rights and obligations, duties and responsibilities, efforts and human health. The law has established that health development aims to increase awareness, willingness and ability of healthy life for every person to realize the optimal degree of public health.

Everyone has equal rights in obtaining optimal health status (Article 4), and the government is responsible for improving public health (Article 9). Under this law, health efforts include: Family Health, Nutrition repairs, Security Food and Drink, Environmental Health, Occupational Health, Mental Health, Communicable Disease, Illness and Healing Health 
Recovery, Health Education, Safety of Pharmaceutical and Medical Devices, Security Addictive substances, School of Health, Exercise Health, Traditional Medicine, Eye Health

\section{DISCUSSION}

Paradigm shift of public service that leads to New Public Service (NPS) has an impact on government bureaucracy to encourage public participation in the public service. So also in the basic services of health conducted by local governments do positive measures to encourage participation by the community are expected to not only the utilization of service but participated in the planning process service.

With respect to the health service in Maros has sought attractive businesses with different forms of community participation to regard the basic services of health, namely:

a. Socialize the Local Regulation No.7 in 2011, it is about health care Levying on health services with the aim of the community to know the costs incurred by the community in order to get health care at Clinics and laboratories with the kind of services that are quite diverse.

b. The perform of health promotion in the interactive dialogue, creation of mass communication, information and education (posters, leaflets, and turning sheet), a public service advertisement creation through print and electronic media, radio broadcasts, interactive dialogue through TV and radio, road show of health/exhibition clinics in the region health services in Maros.

c. Close to the access for medical services through mobile Clinics

d. Through Alert Village/Health Village Post

e. Improvement of quality of service clinics through international standardization of quality of service. (ISO 9001:2008). 
If the described model findings to medical services from the perspective of Participatory Governance is as follows:

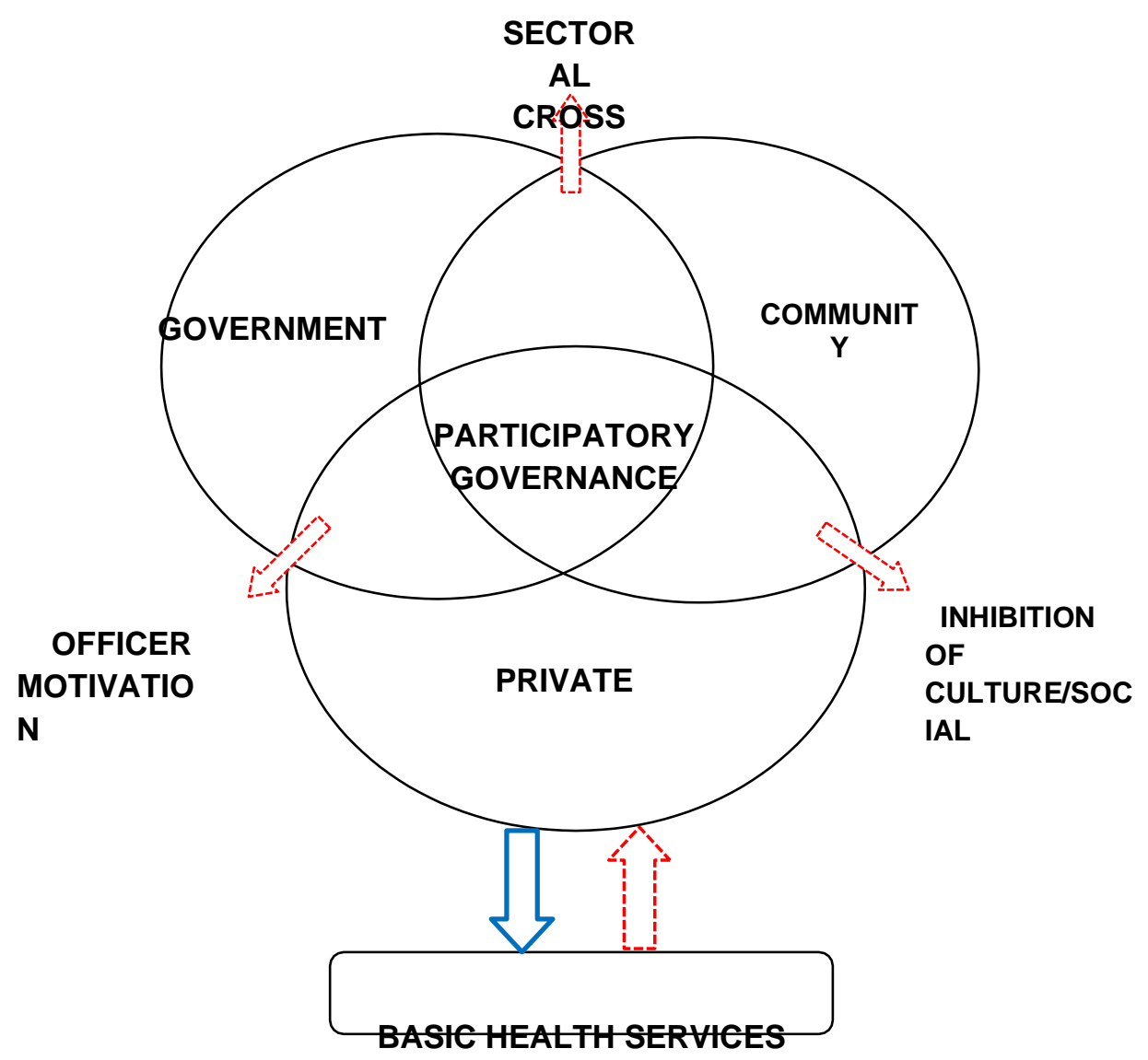

Figure 2. The Findings of the Health Care Model from the Perspective of Participatory Governance

Models of health care from the perspective of Participatory Governance, namely: factually, field conditions associated with health care from the perspective of Participatory Governance gives the explanation that the Participatory Policy Governance Model in the basic services of health deserves to be developed by optimizing as well as strengthen between cooperation and intersectional. The increasing the motivation of health workers as well as eliminate social barriers and cultures in the community.

\section{CONCLUSION}

The empirical basis of this research found several things that can develop community participation in the basic services of health, namely:

1. In order to develop community participation in the basic services of health then, the organizer provides the space to provide opinions and proposals on the problems community 
face, namely through musrenbang, Alert Village and Health Care Forum (FDK/ Forum Peduli Kesehatan) clinic.

2. The organizer provides a clear space to the community to convey complaints directly or indirectly either via the suggestion box or other media (SMS, Fax, telephone, others) so that the community felt it had been granted the right as the owner of the public service.

3. Community involvement in the evaluation process should be through the mechanism of Community Satisfaction Index rating (IKM/ Indeks Kepuasan Masyarakat) that can be relied upon to service improvement in accordance with the expectations of society.

\section{REFERENCE}

Albelson, J and Eyles, 1998. Public Participation and Citizen Governance in Canadian Health System Discussion Paper No.7 Commision On The Future of HealthCare in Canada

Kurniawan, Luthfi J dan Mokkhamad Najib, Paradigma kebijakan Pelayanan Publik. In-Trans Publishing Malang.

Geissel, Brigette, 2004. Participatory Governance Theoritic-analytical Approaches And A case Study, Fifth Pan-Europen International Relations Conference The Hague, September 911

Parasuraman, A, Zeeithaml, V.A. and Berryl. LL, 1985, “A Conceptual Model Of Service Quality and Its Implication for Future Research,” Journal of Marketing Retailing, Vol 49 No.4 : ABI/INFORM Global.

Gronroos, C. (1990). "Relationship Approach to marketing in service Contexts : The Marketing and Organizational Interface", Journal of Business Research, Vol. 20 (January) , pp 3-11

Pollitt, C. (1999) 'Stunded By Stake Holders ? Limits to Collaborate', Public Policy and Administration.

Kotler, P and Andewreasen. 1991. St Rategic Marketing for Non Profit Organization. Eglewood Cliffs, NJ : Preentise Hall

Morgan Collin and Murgatroyd Stephen, 1994, Total Quality Management in the Public Sector. Open University Press.

Lewis C. Robert. Shoemaker Stowe. 1999, “ Customer loyality: The Future of Hospitality Marketing “. International Journal of Hospitality Management 18 (1999) 345-370

Warella, Y. (1997) Administrasi Negara dan Kualitas Pelayanan Publik, Pidato Pengukuhan Guru Besar, FISIP UNDIP

\section{Sumber Inspirasi}

Ma'na, P., Agustang, A., Salusu, J., Ikhsan, A., \& Dirawan, G. D. (2015). Decision making strategic value based local wisdom Tongkonan North Toraja. Man India, 95(3), 633-639.

Upe, A., Salman, D., \& Agustang, A. (2019). The effects of the exploitation of natural resources 
towards risk society construction in Southeast Sulawesi Province, Indonesia. Journal of Degraded and Mining Lands Management, 6(2), 1587.

Awaru, A. O. T., Idris, R., \& Agustang, A. (2018, October). Sexual Education at High School Sinjai East. In 1st International Conference on Social Sciences (ICSS 2018). Atlantis Press.

Idris, M., Ramli, M., Agustang, A., \& Kesuma, A. I. (2015). Bureaucracy Ethics Based in Public Service Local Wisdom in Gowa. Mediterranean Journal of Social Sciences, 6(6 S4), 419419.

Agustang, A., Pada, A. T., \& Bastiana, M. (2018, October). Social Interaction of Local Communities With Migrants and Changes in The Structure of Local Communities (Study on Plural Society in Makassar Industrial Area). In 1st International Conference on Social Sciences (ICSS 2018). Atlantis Press.

Wardah, S., Salman, D., Agustang, A., \& Fahmid, I. M. (2017). The Contestation of Organic and Non-Organic Agricultural Knowledge in Sustainable Agriculture. Mediterranean Journal of Social Sciences, 8(2), 245-245.

Agustang, A. (2018). SIMBOLIKHAJI: Studi Deskriptif Analitik pada Orang Bugis. AlQalam, 15(2), 317-334.

Pannyiwi, R., Agustang, A., Kasnawi, T., Pada, A. T., Yani, A., \& Syam, S. (2020). Social Network for Drug Circulation in Sidenreng Rappang Regency, Indonesia. Systematic Reviews in Pharmacy, 11(9), 575-577.

Agustang, A., \& Soelthan, A. (2015). Analysis of the Inhibiting Factors of Transparency in the Implementation of Local Governance. Mediterranean Journal of Social Sciences, 6(6 S4), 464.

Nain, U., \& Agustang, A. (2020). Analysis On The Utilization Of Village Funds In Cash For Work Program In Bulukumba Regency, South Sulawesi Indonesia. International Journal of Advanced Science and Technology, 29(7s), 2811-2818.

Azis, F., Idris, R., \& Agustang, A. (2017). Involution Fisheries: Post-Study Model of National Program in Integrated Movement at Community Fishermen's Village Development Arungkeke, Jeneponto. Mediterranean Journal of Social Sciences, 8(1), 441.

Agustang, A. D. M. P., \& Nur, H. (2020). Konflik Mahasiswa Parang Tambung Universitas Negeri Makassar. Phinisi Integration Review, 3(1), 46-54.

Rasyid, R., Agustang, A., Maru, R., Agustang, A. T. P., \& Sudjud, S. (2020). PENYULUHAN PENCEGAHAN PENYALAHGUNAAN NARKOBA DI KALANGAN PELAJAR SMP NEGERI 6 DUAMPANUA KABUPATEN PINRANG. JMM (Jurnal Masyarakat Mandiri), 4(2), 116-123.

Rahmania, S., \& Agustang, A. (2017). PRESEPSI MAHASISWA FIK TERHADAP PENYIMPANGAN SEKSUAL LESBIAN (STUDI KASUS PADA MAHASISWA FIK UNM). JURNAL SOSIALISASI, 162-168.

Ashar, A., \& Agustang, A. (2020). Dampak Sosial Dana Desa Dalam Kesejahteraan Masyarakat Di Desa Kalola, Kecamatan Maniangpajo, Kabupaten Wajo. Jurnal Sosialisasi: Jurnal Hasil Pemikiran, Penelitian dan Pengembangan Keilmuan Sosiologi Pendidikan, (1), 19-25.

Yusuf, M., \& Agustang, A. (2020). DINAMIKA PERUBAHAN SOSIAL EKONOMI PADA MASYARAKAT KINDANG KABUPATEN BULUKUMBA. Jurnal Sosialisasi: Jurnal Hasil Pemikiran, Penelitian dan Pengembangan Keilmuan Sosiologi Pendidikan, (2), 3137. 
Fransina, M., \& Andi, A. (2019). THE ANALYSIS OF EXISTENCE OF MIGRATION IN THE CONTEXT OF BASUDARA COMMUNITY IN AMBON CITY, INDONESIA. Russian Journal of Agricultural and Socio-Economic Sciences, 94(10).

Usman, A., Agustang, A., Djalal, D., \& Annas, S. (2018, October). The Contribution Of Supporter Community In Maximizing Their Role For The Advancement Of Makassar Football Club (PSM). In 1st International Conference on Social Sciences (ICSS 2018). Atlantis Press.

Agustang, A., \& Oruh, S. Factors affecting of heropnam of mental disorders in Dadi Regional Hospital in South Sulawesi Province. Man In India, 97(11), 233-244.

Pratiwi, E. L., \& Agustang, A. (2018). PERSEPSI ORANGTUA SISWA TERHADAP TINDAKAN GURU DALAM MENDISIPLINKAN SISWA DI SMK YPKK LIMBUNG. JURNAL SOSIALISASI, 6-10.

Asri, A., Kasnawi, T., \& Agustang, A. Actors' Social Tensions on Traditional Birth Attendants and Midwife Partnerships in Childbirth Assistance (Sociology of Health Study in Bulukumba Regency).

Bahri, S., Kasnawi, T., Agustang, A., \& Adam, A. (2017). Vegetarian Community Social Movement (Analysis of Health Sociology in Makassar). The Social Sciences, 12(10), 1824-1831.

Djalante, A., Agustang, A., Tahmir, S., \& Sahabuddin, J. A Disadvantaged Tribe in Bajoe Village, Bone Regency: A Phenomenological Research on Bajo Tribe's Social Life in Bone Regency, South Sulawesi.

Rahmawati, R., \& Agustang, A. (2018). PERBANDINGAN POLA ASUH ORANG TUA SISWA BERPRESTASI DENGAN SISWA YANG TIDAK BERPRESTASI DI SMA NEGERI 2 GOWA. JURNAL SOSIALISASI, 115-119.

Agustang, A. (2018). PERAN WALI KELAS DALAM PENYELESAIAN KONFLIK ANTAR SISWA DI SMA NEGERI 1 PINRANG. JURNAL SOSIALISASI, 12-16.

Irnawaty, I., \& Agustang, A. (2019). SMARTPHONE ADDICTION PADA MAHASISWA PENDIDIKAN SOSIOLOGI FAKULTAS ILMU SOSIAL UNIVERSITAS NEGERI MAKASSAR. JURNAL SOSIALISASI, 41-46.

Zainuddin, M., \& Agustang, A. (2019). KONTROL SOSIAL ORANGTUA TERHADAP PENGGUNAAN SMARTPHONE PADA REMAJA (STUDI DI DESA GIRINGGIRING KECAMATAN BONTONMPO KABUPATEN GOWA. JURNAL SOSIALISASI, 68-73.

Sofyan, Y., \& Agustang, A. (2018). PENERAPAN MODEL PEMBELAJARAN KOOPERATIF TIPE NHT (NUMBERED HEADS TOGETHER) TERHADAP KEAKTIFAN BELAJAR SISWA KELAS XI IPS 1 SMAN 8 MAKASSAR. JURNAL SOSIALISASI, 158-165.

Agustang, A. (2018). PENERAPAN PUNISHMENT DALAM MEMBENTUK KARAKTER DISIPLIN SISWA DI SMA NEGERI 1 TAKALAR. JURNAL SOSIALISASI, 126-130.

Amiruddin, T. K., Agustang, A., \& Idris, R. (2014). RELIGIOUS CONVERSION IN MARRIED LIFE IN MAKASSAR, THE CASE OF CHRISTIANITY TO ISLAM. JOURNAL OF ACADEMIC RESEARCH, 6(6), 264.

Machmuddin, H., Agustang, A., Kahar, F., \& Bustan, N. (2015). IMPROVING THE QUALITY OF PRIMARY HEALTH SERVICES IN THE PERSPECTIVE OF PARTICIPATORY GOVERNANCE. International Journal of Academic Research, 7(1).

Agustang, A., \& Sahabuddin, J. (2020, October). MODEL KOLABORASI SOSIAL 
PENDIDIKAN KARAKTER DI SEKOLAH SWASTA KECAMATAN BISSAPPU KABUPATEN BANTAENG. In PROSIDING SEMINAR DAN DISKUSI PENDIDIKAN DASAR.

Astinah, A., Idris, R., \& Agustang, A. (2020). AGILE LEADERSHIP AND DIVORCE EDUCATION: STUDY ON WOMEN'S PERCEPTION. Humanities, 8(3), 323-330.

Muis, I., Agustang, A., \& Adam, A. (2020). Elderly Poverty: Social Demographic, Work Distribution, Problem Health \& Social Protection. Asian Journal of Social Sciences \& Humanities Vol, 9(1).

Agustang, A. (2020). Symbolic Violence towards Students in the Context of the Existence of the Stereotypical Frames of Lecturers and Students in the Higher Education System in Indonesia. PalArch's Journal of Archaeology of Egypt/Egyptology, 17(2), 249-258.

Asrifan, A. (2009). Using songs in teaching English language for the young learners. ParePare: unpublished.

Puasa, K., Asrifan, A., \& Chen, Y. (2017). Classroom Talk in Bilingual Class Interaction. Research in Pedagogy, 7(1), 106-121.

Nadirah, N., Tahir, M. H., \& Asrifan, A. (2019). THE ABILITY TO TRANSLATE ENGLISH PHRASES INTO INDONESIAN AND THE DIFFICULTIES FACED BY THE ELEVENTH GRADE STUDENTS OF SMAN 1 PANCARIJANG. JOURNAL OF ADVANCED ENGLISH STUDIES, 2(1), 41-46.

Apdy, A. P. R., \& Asrifan, A. (2019, April). The Chinese mime game in teaching vocabulary on EFL classroom. In PROCEEDINGS OF THE 65th TEFLIN INTERNATIONAL CONFERENCE (Vol. 65, No. 01).

Taslim, T., Asrifan, A., Chen, Y., \& Nurdania, N. R. (2019). CORRELATION BETWEEN STUDENT'S VOCABULARY MASTERY AND SPEAKING SKILL. JOURNAL OF ADVANCED ENGLISH STUDIES, 2(2), 65-76.

Muthmainnah, M., Asrifan, A., Al Yakin, A., \& Sahabuddin, C. (2019, April). The use of dictogloss technique on ELT classroom: An experiment study of students listening comprehension. In PROCEEDINGS OF THE 65th TEFLIN INTERNATIONAL CONFERENCE (Vol. 65, No. 01).

Mutmainnah, M., Azis, S., Maulidya, U., \& Asrifan, A. (2017). Glory Style in Mandar Song Lyrics: A study of Mandar Tribe in South Sulawesi, Indonesia. JOURNAL OF ADVANCES IN LINGUISTICS, 8(1), 1286-1291.

Asrifan, A., Rinantanti, Y., Tang, S., \& Nadirah, N. (2019). THE 3-DIMENSION PICTURES IN INCREASING THE STUDENTS ABILITY AND INTEREST TO WRITE DESCRIPTIVE COMPOSITION. JOURNAL OF ADVANCED ENGLISH STUDIES, 2(1), 19-30.

Asrifan, A., Nadira, N., \& Haedar, H. (2018). IMPROVING STUDENTS'READING COMPREHENSION OF DESCRIPTIVE TEXT THROUGH COLLABORATIVE MURDER. JOURNAL OF ADVANCED ENGLISH STUDIES, 1(2), 21-31.

Asrifan, A. (2015). Analysis of English Students' Learning Style in Bilingual Class. International Journal of Literature and Arts, 3(4), 34.

Farahdiba, S., \& Asrifan, A. (2016). Speaking Ability and Psychological Barriers of the Second Year Students of Hotel Department of SMKN 1 Sidenreng Kabupaten Sidrap in Speaking English. Asian EFL Journal, (89), 41. 
Asrifan, A. (2012). Increasing the Students Ability to Write Descriptive Composition at SMP Negeri 13 Parepare by using the 3-Dimension Pictures.

Tang, S., Asrifan, A., Chen, Y., Haedar, H., \& Agussalim, M. (2019). THE HUMOR STORY IN TEACHING READING COMPREHENSION. JOURNAL OF ADVANCED ENGLISH STUDIES, 2(2), 77-87.

Nurwanti, N., Asrifan, A., \& Haedar, H. (2019). THE APPLICATION OF COOPERATIVE LEARNING: JIGSAW II TECHNIQUE IN IMPROVING STUDENTS'READING COMPREHENSION OF EXPOSITORY TEXT. JOURNAL OF ADVANCED ENGLISH STUDIES, 2(1), 31-40.

Asrifan, A. (2016). The Effectiveness of Think-Pair-Share Technique in Improving Studentsâ€TM Speaking Ability and Interest. English Literature and Language Review, 2(3), 24-35.

Asrifan, A., Muthmainnah, M., Al-Yakin, A., Sahabuddin, C., \& Haedar, H. (2018). THE CAUSEEFFECT TECHNIQUE IN TEACHING RECOUNT WRITING. JOURNAL OF ADVANCED ENGLISH STUDIES, 1(2), 63-72.

Asrifan, A., Vargheese, K. J., Syamsu, T., \& Amir, M. (2020). ESP COURSE DESIGN: THE NEED ANALYSIS ON TOURISM DEPARTMENT IN INDONESIA VOCATIONAL HIGH SCHOOLS. JOURNAL OF ADVANCED ENGLISH STUDIES, 3(2), 69-77.

Asrifan, A., Ghofur, A., \& Azizah, N. (2020). Cheating Behavior in EFL Classroom (A Case Study at Elementary School in Sidenreng Rappang Regency). OKARA: Jurnal Bahasa dan Sastra, 14(2), 279-297.

Nadirah, N., Asrifan, A., Vargheese, K. J., \& Haedar, H. (2020). INTERACTIVE MULTIMEDIA IN EFL CLASSROOM: A STUDY OF TEACHING READING COMPREHENSION AT JUNIOR HIGH SCHOOL IN INDONESIA. JOURNAL OF ADVANCED ENGLISH STUDIES, 3(2), 131-145.

Muthmainnah, A. R., Atmowardoyo, H., Salija, K., \& Asrifan, A. (2020). Literary Work as Teaching Materials: A Study of Students and Lecturers Needs Analysis. Solid State Technology, 63(5), 394-407.

Tilome, A. A., Agustang, A., Jasruddin, M. S., \& Asrifan, A. (2020). Social Exchange of Political Elites in the Regional Leader Election of Gorontalo Province, Indonesia. Solid State Technology, 63(5), 521-531.

Pacinongi, A., \& Asrifan, A. (2020). Bimbingan Pengawas Berkelanjutan dalam Mewujudkan Pendidikan Karakter Bangsa dalam Kegiatan Belajar Mengajar Penjaskes. Celebes Education Review, 2(1), 1-7.

Gunawan, G., \& Asrifan, A. (2020). Penerapan Kerja Kelompok Kegiatan MGMP Guru Ekonomi dalam Menyusun RPP untuk Meningkatkan Kompetensi Pedagogik. Celebes Education Review, 2(1), 31-36.

Yusuf, I., \& Asrifan, A. PENINGKATAN AKTIVITAS KOLABORASI PEMBELAJARAN FISIKA MELALUI PENDEKATAN STEM DENGAN PURWARUPA PADA SISWA KELAS XI IPA SMAN 5 YOGYAKARTA. Editorial Team, 32.

Al Yakin, A., Sahabuddin, C., Rahayu, A., Fitrah, N., \& Arifin, M. (2020). Political Celebrification and Electability: A Study of Political Phenomena Imaging in Election Polewali Mandar District, West Sulawesi, Indonesia. Solid State Technology, 63(5), 632-646.

Junaedah, S. B. T., \& Ahmad, M. A. (2020). The Outdoor Learning Modules Based on Traditional Games in Improving Prosocial Behaviour of Early Childhood. International Education Studies, 13(10). 
Octaberlina, L. R., \& Muslimin, A. I. (2020). Efl students perspective towards online learning barriers and alternatives using moodle/google classroom during covid-19 pandemic. International Journal of Higher Education, 9(6), 1-9.

Octaberlina, L. R., \& Anggarini, I. F. (2020). Teaching vocabulary through picture cards in Islamic Elementary School: a case study in Nida Suksa School, Thailand. Jurnal Madrasah, 13(1), 26-38.

Octaberlina, L. R. (2016). Plagiarism in English language theses in Indonesia. Jurnal Ilmu Pendidikan, 14(3).

Octaberlina, L. R., \& Anggarini, I. F. (2020). Teaching vocabulary through picture cards in Islamic Elementary School: a case study in Nida Suksa School, Thailand. Jurnal Madrasah, 13(1), 26-38.

Asrifan, A., Zita, C. T., Vargheese, K. J., Syamsu, T., \& Amir, M. (2020). THE EFFECTS OF CALL (COMPUTER ASSISTED LANGUAGE LEARNING) TOWARD THE STUDENTS'ENGLISH ACHIEVEMENT AND ATTITUDE. JOURNAL OF ADVANCED ENGLISH STUDIES, 3(2), 94-106.

Asrifan, A. (2021). ACADEMIC WRITING. LawArXiv. January, 2. https://doi.org/10.31228/osf.io/x2s7e

Asrifan, A. (2020). TUTORIAL PENGGUNAAN QUIZIZZ (www. quizizz. com) PADA PEMBELAJARAN. https://doi.org/10.31219/osf.io/kqnza

Asrifan, A. (2021). Abd Ghofur.“. THE USE OF READING CIRCLES IN INCREASING STUDENTS SPEAKING ABILITY AT THE ELEVENTH GRADE SMK NEGERI, 1. https://doi.org/10.31219/osf.io/8vjxy

Asrifan, A. (2020). Pandemic, Humanity and Education. https://doi.org/10.31219/osf.io/q2gpk

Asrifan, A. (2021). USING CAT AND MOUSE GAME TO IMPROVE STUDENT'S SPEAKING ABILITY AT THE ELEVENTH GRADE OF MA YMPI RAPPANG. https://doi.org/10.31219/osf.io/phtvn

Asrifan, A., \& Ghofur, A. (2021). THE USE OF READING CIRCLES IN INCREASING STUDENTS SPEAKING ABILITY AT THE ELEVENTH GRADE SMK NEGERI 1 PANCARIJANG. https://doi.org/10.31219/osf.io/8vjxy

Asrifan, A. (2021). Book Review: Halliday. 1989. Spoken and Written Language. Oxford University Press. https://doi.org/10.31219/osf.io/ej8tb

Asrifan, A., \& Ghofur, A. (2021). TALK, ACTION, SILENCE, INTERRUPTION AND THEIR IMPLICATIONS IN BUGINESE SOCIETY (SOPPENG REGENCY). https://doi.org/10.31219/osf.io/pv3ku

Asrifan, A. (2020). PENILAIAN BERBASIS ANDROID MENGGUNAKAN APLIKASI PLICKERS. https://doi.org/10.31219/osf.io/htreq

Sapulette, A. A., Agustang, A., \& Syukur, M. Actor Construction in the Frame of Diversity to Achieve Social Harmony in the Life of Tamilouw Village Society Seram Island-Maluku.

Amiruddin, T. K., Agustang, A., \& Idris, R. (2014). RELIGIOUS CONVERSION IN MARRIED LIFE IN MAKASSAR, THE CASE OF CHRISTIANITY TO ISLAM. JOURNAL OF ACADEMIC RESEARCH, 6(6), 264.

Machmuddin, H., Agustang, A., Kahar, F., \& Bustan, N. (2015). IMPROVING THE QUALITY OF PRIMARY HEALTH SERVICES IN THE PERSPECTIVE OF PARTICIPATORY GOVERNANCE. International Journal of Academic Research, 7(1). 
Agustang, A., \& Sahabuddin, J. (2020, October). MODEL KOLABORASI SOSIAL PENDIDIKAN KARAKTER DI SEKOLAH SWASTA KECAMATAN BISSAPPU KABUPATEN BANTAENG. In PROSIDING SEMINAR DAN DISKUSI PENDIDIKAN DASAR.

Mutiara, I. A., Agustang, A., Adam, A., Upe, A., \& Equatora, M. A. (2020). The dynamics of prostitutes lives in metropolitan cities. Journal of Critical Reviews. https://doi. org/10.31838/jcr, 7, 165.

Haulussy, R. H., Najamuddin, I. R., \& Agustang, A. D. M. P. (2020). The sustainability of the Sasi Lola tradition and customary law (Case study in Masawoy Maluku, Indonesia). Intl J Sci Technol Res, 9(2), 5193-5195.

Agustang, A. (2020). Symbolic Violence towards Students in the Context of the Existence of the Stereotypical Frames of Lecturers and Students in the Higher Education System in Indonesia. PalArch's Journal of Archaeology of Egypt/Egyptology, 17(2), 249-258.

Agustang, A. (2015). Dasar-Dasar Filsafat Penelitian Untuk Pengembangan Ilmu.

Agustang, A. T. P. Muh. Said, dan Rusman Rasyid. 2015. Perkembangan Peran Jender Dalam Prespektif Teori Androgini, 1-8.

Rasyid, R., Agustang, A., Agustang, A. T. P., Bastiana, B., \& Najamuddin, N. Analisis Faktor Yang Mempengaruhi Status Kemiskinan Rumah Tangga Pada Wilayah Central Bussiness District (CBD) di Kota Makassar. Majalah Geografi Indonesia, 34(1), 43-52.

Asmi, A. S., Kasnawi, M. T., Agustang, A., \& Yani, A. (2020). Sociocultural Transformation in Efforts to Reduce Mortality of Infants in Bone Regency, Indonesia. Systematic Reviews in Pharmacy, 11(10), 762-765.

Agustang, A. (2020, October). Social Actions of Galla Actors in the Kaemba Maros Traditional Village Community Sulawesi Selatan. In 3rd International Conference on Social Sciences (ICSS 2020) (pp. 748-753). Atlantis Press.

Agustang, A. (2020). The Symbolic Violence Towards Private School Students Through The Frame Stereotype In Bantaeng District Of Indonesia. Prosiding ICoISSE, 1(1), 578-588.

Ariani ${ }^{1}$, A. I., Agustang, A., Adam, A., \& Alimsyah, S. (2020). INSTITUTIONAL FAILURES IN THE WORLD OF EDUCATION IN SCHOOLS FOR CHILDREN VICTIMS OF PARENTS. Asian Journal of Social Sciences \& Humanities Vol, 9, 2. 